\title{
IMPROVING THERMAL PERFORMANCE OF A DOUBLE- SLOP SOLAR STILL UNDER HOT, HUMID AND DUSTY CLIMATIC CONDITIONS \\ Almuhanna, E. A.
}

Department of Agricultural Systems Engineering, College of Agricultural Sciences and Food, King Faisal University, Hofuf, Saudi Arabia

e-mail: ealmuhanna@kfu.edu.sa, ealmuhanna@yahoo.com

\begin{abstract}
To performance comparative studies, three sets of integrated solar still double-slope (SSDS) were constructed and examined under hot, humid and dusty climatic conductions of Al-Ahsa (eastern province), Saudi Arabia. The SSDSs were identical in all aspects but the first set was without condenser (SSDS), the second one with condenser (SSDSC), and the third set with condenser and solar water heater (SSDSCSH) in order to raise the brackish water temperature before entering the solar still. The condensers were provided with cold water from an evaporative cooling system reservoir. Experimental results revealed that the distilled water production from the three distillers SSDS, SSDSC, and SSDSCSH, respectively, was 1.98, 4.82, and 6.65 litres per square meter per day with volumetric thermal efficiencies of 18.7 , 46.0 and $64.4 \%$. The integrated double-sided solar distiller with condenser only (SSDSC) increased the production of distilled water and the volumetric thermal efficiency by $143.4 \%$ and $146.0 \%$, respectively, as compared with (SSDS). The solar water heater connected to the third set (SSDSCSH) increased the basin water temperature resulting in increasing the evaporation rate and the production of distilled water. Therefore, this system increased the production of distilled water and the volumetric thermal efficiency by $38.0 \%$ and $40.0 \%$, respectively, as compared with the second set (SSDSC). Moreover, the third set increased the production of distilled water and the volumetric thermal efficiency by $235.9 \%$ and $244.4 \%$, respectively, as compared with the first set of solar stiller (SSDS) The accumulated of atmospheric dust on the glass cover of solar distillers reduced the production of distilled water and efficiency by $63 \%$. Therefore, the cleanliness of the solar still glass cover was crucial to provide and maintain the maximum production. Ultimately, The $\mathrm{pH}, \mathrm{EC}$, and TDS of the distilled water were found to be much lower $(7.8,42.9 \mu \mathrm{s} / \mathrm{cm}$, and $39.7 \mathrm{ppm}$, respectively) than those of the brackish water $(8,1417 \mu \mathrm{s} / \mathrm{cm}$, and $1392 \mathrm{ppm}$, respectively).

Keywords: Double-slope solar still, solar water heater, Condensers, Evaporative cooling
\end{abstract}

\section{INTRODUCTION}

Many arid regions of the world have large populations that do not have access to sufficient quantities of quality drinking water. Although water is often available, its quality is poor, which prevents its use (Mechell et al., 2011). The problem is more severe in desert countries such as the Gulf Cooperation Council (GCC) countries and in particular, the Kingdom of Saudi Arabia (KSA), where fresh water shortage is a serious problem. Most of these countries, however, enjoy abundant and free solar energy of high intensity, and solar desalination may be an ideal technology that can partially solve the fresh water shortages for domestic and agricultural use (Radhwan, 2004). The regions in which these problems persist are often located where the 
potential to use solar radiation for distillation is great. Although solar distillation units typically have a high initial cost, their operation and maintenance costs are minimal (Mechell et al., 2011). In Saudi Arabia, distilled water is the main source for domestic consumption, and this use of distilled water is one of the highest in the world (Aljohani, 2004). The water produced by a solar distiller is pure and is suitable for residential applications (Almuhanna, 2014). Furthermore, solar distillation is a safe and economical method for the purification of water (Swetha and Venugopal, 2011).

A variety of solar desalination units have been developed and constructed. A key aspect to improve the overall efficiency is a better understanding of the thermodynamics of the process, which will lead to the design of a more efficient solar still. Although a system may be technically efficient, it may not be economical. The materials for construction, the plant size and location, and the operating costs must all be taken into account. Therefore, efficiency and economics need to be considered when choosing a solar desalination system (Goosen et al., 2003). Moreover, combining the solar still with an air-conditioning system can increase the condensate output from the solar still (Abdel-Rehim and Lashine, 2012). In a recent study, Almuhanna (2014) improved the productivity of a single-slope solar still by combining the solar still with a condenser supplied with cooled water from an evaporative cooling system. The connection of the solar still to the condenser increased the production of stilled water and the volumetric thermal efficiency by $55.41 \%$ and $30.1 \%$, respectively. Over the years, the acceptance of solar distillation has been affected by the low purification yield per square meter of solar still surface, the local commitment to properly operate and maintain the solar stills, and the important role of the relatively high initial capital investment (Chaibi, 2000; Goosen et al., 2000).

Some techniques, such as multi-effect evaporation, multistage flash distillation, thin film distillation, vapor compression, reverse osmosis and electro-dialysis, are energy intensive and operating costs are high. Although these technologies are expensive, only small amounts of freshwater are produced. The direct use of solar energy represents a promising option to eliminate the major operating cost (Helmy et al., 2011). A study to identify parameters was performed by Al-Hinai et al. (2002) on a conventional double-sloped single-basin solar still under climatic conditions of the sultanate of Oman in the Gulf region. Under optimum design conditions, the stiller produced an average annual solar yield of approximately $4 \mathrm{l} / \mathrm{m}^{2}$ per day.

Al-Hayek and Badran (2004) examined the use of solar energy in two different types of solar stills and the factors that influenced the production of the solar stills. They found that the production and efficiency of an asymmetric greenhouse-type still (ASGHT) with mirrors on the inside walls were higher than those of a symmetric greenhouse-type still (SGHT). The performance of a single-basin solar still with the entering brine flowing between double glass glazings was investigated by Abu-Arabi et al. (2002), and the arrangement lowered the glass temperature and thus increased the water to glass temperature difference.

The practical uses of solar energy in the Kingdom of Saudi Arabia (KSA) include the following: lighting, cooling, cooking, heating water, drying 
crops and fruits, desalinating water, operating irrigation pumps and meteorological stations, lighting for traffic lights, roads and tunnels, and lighting for road instruction signals, among others (Hepbasli and Alsuhaibani, 2011). Solar radiation can be the source of heat energy to evaporate brackish water or seawater, which is then condensed as pure water (Badran and AbuKhader. 2007; Hepbasli and Alsuhaibani, 2011). The KSA is between latitudes $31^{\circ} \mathrm{N}$ and $17.5^{\circ} \mathrm{N}$ and longitudes $50^{\circ} \mathrm{E}$ and $36.6^{\circ} \mathrm{E}$. Therefore, the $\mathrm{KSA}$ is located in the middle of one of most productive solar regions in the world, which receives the most potent type of sunlight. The average annual solar radiation on the Arabian Peninsula is approximately $2200 \mathrm{kWh} / \mathrm{m}^{2}$ (Hepbasli and Alsuhaibani, 2011). The KSA is an arid desert country with no perennial rivers, streams or permanent freshwater lakes. Rainfall is scarce and infrequent and is associated with high evaporation rates and sandy land dissipation rates. The available ground-waters are deeply buried and do not recharge (Radhwan and Fath, 2005).

Al-Ansari (2013) studied the technologies related to the concentration of solar power along with water desalination demands and freshwater availability and found that groundwater resources were jeopardized. $\mathrm{He}$ evaluated solar energy accessible resources and the costs of integrating this alternative energy source, which included the desalination of water, the longstanding scenarios of integrating power production technologies into the water sectors, and the quantifying of the socio-economic and environmental costs of this alternative energy option within the Gulf Cooperation Council countries of Qatar, Saudi Arabia, Kuwait, Oman, UAE, and Bahrain.

Evaporative cooling involves no change in the enthalpy (heat content) of the air mixture. Rather, as water evaporates, it removes heat from the air and thus reduces the temperature. The systems of evaporative cooling are based on the conversion of sensible heat into the latent heat of evaporated water, with the water supplied mechanically. Evaporative cooling has long been used to improve the thermal environment and comfort of humans, plants and animals. It remains one of the most available techniques to reduce air dry-bulb temperature to a more comfortable range. Additionally, evaporative cooling is reliable and requires minimum power consumption (Ahmed et al., 2011). Solar water heaters are used worldwide in countries where sunlight is abundant (Diekmann, 2008; Li et al., 2013). The flat-plate solar collector is the most important type of solar collector because it has a simple design, with no moving parts, and requires little maintenance. It can be used for a variety of applications in which temperatures that range from $40^{\circ} \mathrm{C}$ to approximately $100^{\circ} \mathrm{C}$ are required (Kalogirou, 2005; Khan and Islam, 2011). Badran and Al-Tahaineh (2005) integrated a conventional flat-plate collector with a solar stiller to augment the production rate. They found that the mass of distilled water increased by $52 \%$ when the still was coupled with flat-plate collector.

The main objectives of this study were to investigate and to evaluate the effects of integrating a solar still with a condenser supplied with cooled water from an evaporative cooling system and with a solar collector on the volumetric thermal efficiency and the production of water from a double-slope 
solar stiller under hot, humid and dusty climatic conditions of Al-Ahsa, Saudi Arabia.

\section{MATERIALS AND METHODS}

\section{Experimental setup}

Three identical double-slope type solar stills were designed, constructed, and tested during June 2014 at the Agricultural and Veterinary Training and Research Station of King Faisal University, Saudi Arabia (latitude angle $25.3^{\circ} \mathrm{N}$, longitude angle $49.5^{\circ} \mathrm{E}$, and mean altitude above sea level $172 \mathrm{~m}$ ). The first solar still was operated as a stand-alone unit (SSDS), the second unit was connected to a condenser supplied with cooled water from an evaporative cooling system (SSDSC) and the third unit was connected to a condenser similar to that in the second unit and a solar water heater connected to the solar still water basin (SSDSCSH). The geometric characteristics of the still are as follows: eaves height, $0.35 \mathrm{~m}$, width, $1.0 \mathrm{~m}$, length, $2.0 \mathrm{~m}$, still rafter angle, 35으, rafter length, $0.61 \mathrm{~m}$, net glass surface area, $1.74 \mathrm{~m}^{2}$ (0.87 $\mathrm{m}^{2}$ each side), basin height, $0.2 \mathrm{~m}$, and basin surface area, $2.0 \mathrm{~m}^{2}$ as shown in Fig. (1).

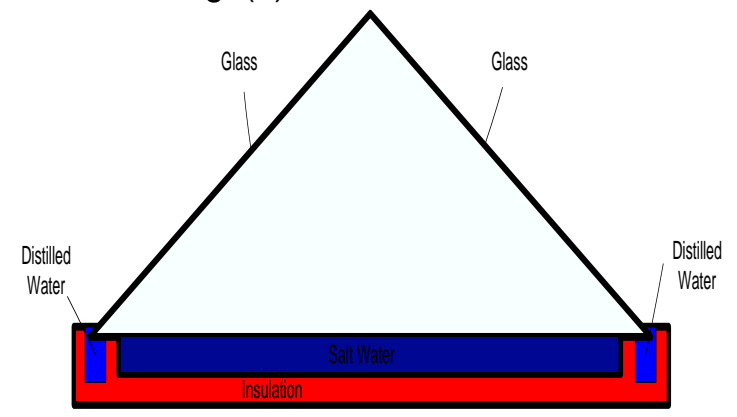

Fig. (1): Stand-alone double-slope solar still (SSDS)

The basin of the solar still was made of galvanized stainless steel 1.5 $\mathrm{mm}$ thick with a maximum height of $20 \mathrm{~cm}$. The galvanized basins were firstly painted with red-lead primer and after that by matte black paint to maximize the absorption rate of solar radiation. The bottom and sides of the solar still were insulated from the outside with rock wool insulation $5 \mathrm{~cm}$ thick, with a thermal conductivity of $0.045 \mathrm{~W} / \mathrm{m} \stackrel{\circ}{\circ} \mathrm{C}$ to minimize the heat loss from the bottom and side walls of the solar still. Each solar still was covered by $3 \mathrm{~mm}$ thick of clear glass with a maximum effective transmissivity of 0.90 . Previous experimental results showed that a solar still with a glass cover plate $3 \mathrm{~mm}$ thick was $16.5 \%$ more productive than a still with a glass cover $6 \mathrm{~mm}$ thick (Murugavel et al., 2008). The following specifications were required for the glass cover used in the solar still: a minimum amount of absorbed heat energy, a minimum amount of reflection of solar radiation, a maximum transmittance of solar radiation, and a high thermal resistance to heat loss from the basin to the surroundings. The glass covers were sealed with silicone rubber, which played an important role in promoting efficient condensation because it could accommodate the expansion and contraction between dissimilar materials. The volume of brackish water in the basin was 
maintained at 50 liters. A feeding tank was located beside the still as a constant head tank, which was used to control the level of brackish water inside the solar still. A constant water level in the basin was maintained with a floating ball $2.5 \mathrm{~cm}$ deep.

The solar stills were orientated in an east-west direction, with the southern longitudinal sides facing the sun, and solar radiation was transmitted through the glass covers and was absorbed by the brackish water and the bottom of the basin. The sensible heat absorbed by the brackish water evaporated the water, which was transferred to the glass as a water vapour where it condensed on the underside of the glass cover (water vapour condenses in a film on the inside surface at a temperature below the dewpoint temperature of the inside moist air). Another part of the heat from the water was transferred to the glass cover by the free convection of air; the remaining heat was transferred by radiation. The glass cover transferred the heat to the atmosphere by convection and radiation. Some of the heat energy was accumulated in the solar still in the form of the sensible heat of the still and of the water. Some of the heat energy might have been lost because of the leakage of water vapour or water from the still. The condensate water flowed via gravity into the collection troughs at the lower edges of the tilted glass covers (the glass cover was at a sufficient slope of 350); therefore, the surface tension of the water caused it to flow into the troughs without dripping back into the basin). Two plastic containers were used to collect the distilled water produced from each solar still.

To improve the thermal performance of the solar still (SSDS), the second and third sets were connected to condenser. The operation of the condenser was dependent upon cooled water (water temperature at the wetbulb temperature of the ambient air) from the water storage tank of the greenhouse evaporative cooling system, which was situated beside the solar stills as revealed in Fig. (2). The condenser was located $0.8 \mathrm{~m}$ from the evaporative cooling system to maintain the cooled water at a lower temperature, and it consisted of two cylindrical tubes made of galvanized stainless steel $1.5 \mathrm{~mm}$ thick. The outer tube (cold water cylinder) was $0.4 \mathrm{~m}$ in diameter, $1 \mathrm{~m}$ long, and covered with glass wool insulation, whereas the inner tube (water vapor) was $0.2 \mathrm{~m}$ in diameter and $1 \mathrm{~m}$ long. The function of the condenser was to provide a surface temperature (inside surface of the inner tube) lower than the dew-point temperature of the water vapour. Consequently, the condensation process and the phase-change of water vapour into freshwater were accelerated, as mentioned by Almuhanna (2014).

The third solar still with condenser was connected to a solar water heater (SSDSSH) as demonstrated in Fig. (3). The solar heater was installed $1 \mathrm{~m}$ from the solar still. The solar heater consisted of six components, a heater box, an absorber plate, a copper pipe, insulation material, a glass cover and an insulated storage tank. The heater box was rectangular in shape and made of aluminum bars and sheets. The dimensions of the heater box were $2.0 \mathrm{~m}$ long, $1.0 \mathrm{~m}$ wide and $0.15 \mathrm{~m}$ deep, with a net upper surface area of $2.0 \mathrm{~m}^{2}$. The absorber plate was formed from an aluminum sheet $(2.0$ $\mathrm{mm}$ thick), which is a good conductor of heat (thermal conductivity $204 \mathrm{~W} / \mathrm{m}$ 
$\left.{ }^{\circ} \mathrm{C}\right)$. The plate was painted with matte black paint to absorb the maximum amount of the solar radiation flux incident on it. Twenty $12.7 \mathrm{~mm}$ diameter copper pipes were attached to the upper surface of the absorber plate (in the lateral direction). These pipes were used to increase the volume of water per unit surface area and to increase the heat transfer between the absorber plate and the copper pipes. They were also painted with matte black paint. The copper pipes were connected to two header tubes (19.05 mm diameter) running in a parallel direction. In the bottom and sides of the heater box, 100 $\mathrm{mm}$ thick fiberglass wool insulation was placed to reduce the heat losses from the sides and back of the solar heater. To reduce the reflection of radiation and the heat loss by convection, a clear glass cover $6 \mathrm{~mm}$ thick was placed on the heater box. The solar heater was used to heat the water in the solar still basin, where the water moved by natural convection.

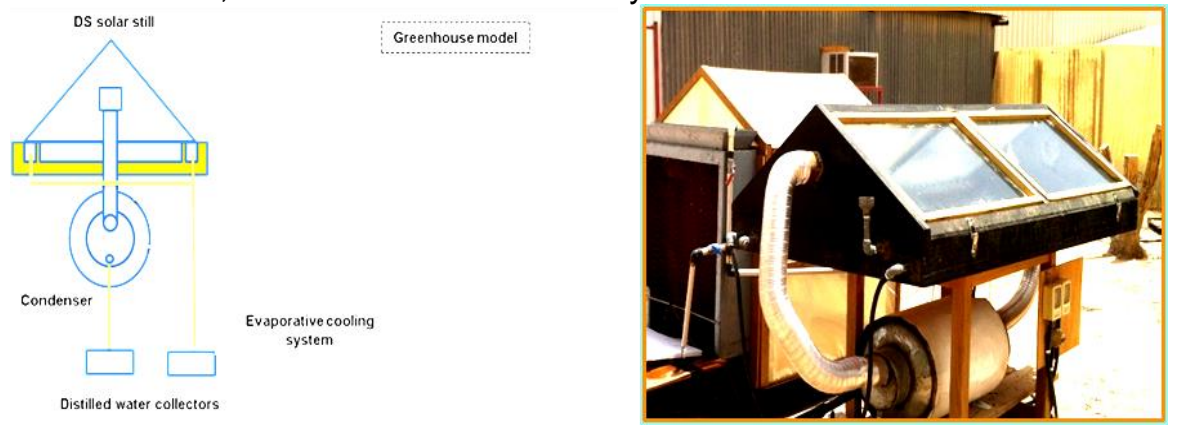

Fig. (2): Double-slope solar still connected to a condenser (SSDSC).
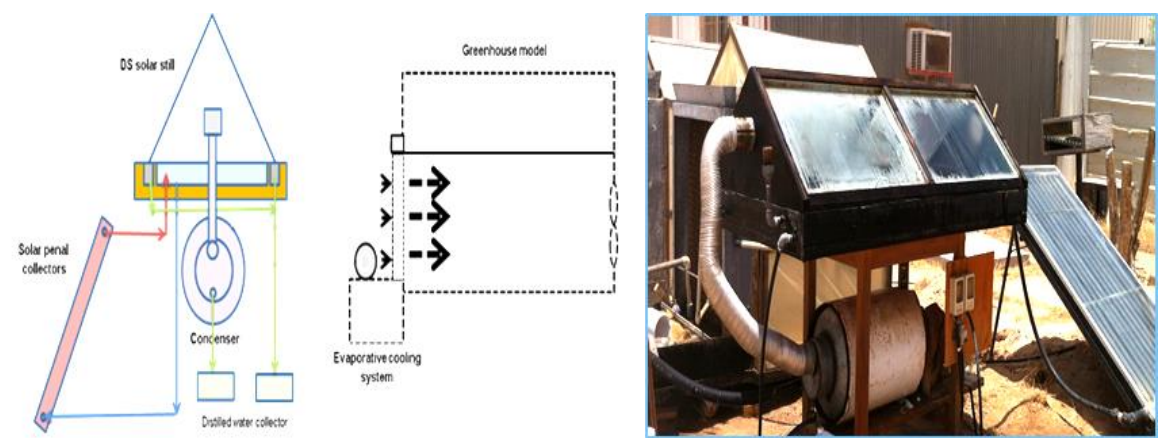

Fig. (3): Double-slope solar still connected to a condenser and a solar water heater (SSDSSH)

Two experimental gable-even-span greenhouse forms were designed, constructed, and installed beside the second and third solar stills so that the evaporative cooling system could provide cooled water for the two condensers. The geometric characteristics of the gable-even-span forms greenhouse are as follows: eaves height, $1.25 \mathrm{~m}$; gable height, $0.30 \mathrm{~m}$; span angle, $31^{\circ}$; width, $1.30 \mathrm{~m}$; length, $1.25 \mathrm{~m}$; floor surface area, $1.625 \mathrm{~m}^{2}$; and volume, $2.1 \mathrm{~m}^{3}$. The greenhouse structural frame was made of wooden plates $(0.05 \mathrm{~m} \times 0.05 \mathrm{~m})$ and was covered with a single polyethylene sheet $200 \mu \mathrm{m}$ thick (PE, UV). The greenhouses were orientated in the east-west 
direction. The evaporative cooling system consisted of one extracting fan with the following specifications: $0.4 \mathrm{~m}$ diameter, $900 \mathrm{~m}^{3} / \mathrm{h}$ discharges, $1 \mathrm{~m}^{2}$ of cooling pads, a $0.16 \mathrm{~m}^{3}$ water reservoir, and a one-third hp water pump.

Brackish water has the following specification; $\mathrm{pH} 8, \mathrm{EC} 1417 \mu \mathrm{s} / \mathrm{cm}$, and TDS 1392 ppm was used as the feed into the solar still. The concentration was usually allowed to double before the brackish water was removed, and thus half of the water in the feed was distilled off.

Measurements and data acquisition

A meteorological station (HOBO U30-NRC Weather Station, Onset Computer, USA) was functioned to measure the solar radiation flux incident on a horizontal surface, the air temperature, the wind speed and its direction, and the air relative humidity. The inside variables of the solar stills included; air temperature $\left(T_{a}\right)$, brackish water temperature $\left(T_{w}\right)$, still vapour temperature $\left(T_{v}\right)$ inside glass temperature $\left(T_{g i}\right)$ and outside glass temperature $\left(T_{\text {go }}\right)$ were measured and recorded during the experimental work using different temperature sensors connected to the same system. The hourly production of distilled water was recorded with a graduated cylinder (1000 $\mathrm{ml}$ ). Additionally, the quality parameters, such as the $\mathrm{pH}$, electrical conductivity (EC), and total dissolved solids (TDS), of the distilled water produced by the solar distiller were also measured and recorded.

\section{Thermal efficiency of the solar still}

The volumetric thermal efficiency of the solar stills was defined as the ratio of the rate of heat transfer $\left(\mathrm{q}_{\mathrm{ev}}\right)$ in the still by evaporation-condensation in $\mathrm{W} \mathrm{m}^{-2}$ to the solar radiation $(\mathrm{R})$ on the still in $\mathrm{W} \mathrm{m} \mathrm{m}^{-2}$, calculated by the following equation (ASHRAE, 2005; Duffie and Beckman, 2006):

$$
n_{\text {vol }}=\frac{q_{e v}}{R}, \quad \%
$$

This equation is usually integrated over some extended period (e.g., day or month) to clarify long-term thermal performance. However, in practice, because some freshwater product was lost back into the basin of the still (by dripping from the glass cover and by leaking from the collecting troughs), less product was available than was indicated by the above equation. Therefore, the volumetric thermal efficiency of a solar still determined from experimental measurements, which represents the production of freshwater, is primarily computed using the following equation (ASHRAE, 2005; Duffie and Beckman, 2006):

$$
\eta_{\text {vol }}=\frac{m_{p} h_{f g}}{3.6 A_{b} R}, \quad \%
$$

Where, $m_{p}$, is the rate at which the distillate of freshwater is produced from the still in $\mathrm{kg} \mathrm{h}^{-1}, \mathrm{~h}_{\mathrm{fg}}$, is the latent heat of vaporization in $\mathrm{kJ} \mathrm{kg}^{-1}$, and $A_{b}$, is the surface area of the basin in $\mathrm{m}^{2}$.

\section{Thermal Performance of Solar Water Heater}

Optimum design of a solar heating system can increase the amount of solar energy converted into useful heat gain, and consequently provided a 
specific amount of energy consumption. The thermal performance of the solar heating system can be described as follows (Duffie and Beckman, 2006):
SR
$=\mathbf{R}_{\mathrm{t}} \mathbf{A}_{\mathrm{c}}$,
Watt
(3)
$Q_{a} \quad=R_{t} A_{c}(T \alpha)$
Watt
(4)

Where, $\mathrm{SR}$, is the solar radiation available in $\mathrm{W}, \mathrm{R}_{\mathrm{t}}$, is the solar radiation flux incident on a tilted surface in $\mathrm{W} \mathrm{m}^{-2}, \mathrm{~A}_{\mathrm{c}}$, is the surface area of solar heating system in $\mathrm{m}^{2}, \mathrm{Q}_{\mathrm{a}}$, is the absorbed solar radiation by solar heating system in $\mathrm{W} \mathrm{m}^{-2},(\mathrm{Ta})$, is the optical efficiency (the product of effective transmittance of glass cover, $\mathrm{T}$, and effective absorptance of absorber plate, $\alpha$ ), decimal

$T_{\text {glass }}=0.90-0.00437 \exp [0.0936(\theta-30)[$

$\alpha=0.95-0.00476 \exp [0.0940(\theta-35)]$

$\theta=$ the angle of incidence of solar radiation, degree

$\theta=\operatorname{arcos}\left(\cos \psi \cos \gamma_{s} \sin \beta+\sin \psi \cos \beta\right)$

$\psi=$ the solar altitude angle, degree

$\psi=\arcsin (\cos \Phi \cos \delta \cos \omega+\sin \Phi \sin \delta)$

$\Phi=$ = the latitude angle of the location $\left(25.3^{\circ} \mathrm{N}\right)$

$\delta=$ the solar declination angle, degree

$\delta=23.45 \sin [(n+284) 360 / 365]$

$\mathrm{n}=$ the number of the day from the first of January

$\beta=$ the tilt angle of solar heating system, degree

$\beta=90-\psi$

$\mathrm{V}_{\mathrm{s}}=$ the solar azimuth angle, degree

$\omega=$ the solar hour angle, degree

$$
\gamma_{\mathrm{s}}=\arcsin \left[\frac{\cos (\delta) \sin (\omega)}{\cos (\psi)}\right]
$$

$\omega=($ LAT - 12) 15

LAT $=$ the local apparent time

The absorption efficiency $\left(\eta_{p}\right)$ of the absorber plate to the solar radiation can be computed from the following equation (Abdellatif et al., 2009):

$$
\eta_{\mathrm{a}}=\frac{\mathrm{Q}_{\mathrm{a}}}{\mathrm{R}_{\mathrm{t}} \mathrm{A}_{\mathrm{c}}} \times 100, \%
$$

To use and utilize the solar energy for any specific applications, it is very imperative to study and know the position of the sun at a place in question. The position of the sun at any given time at Al-Ahsa is given by the latitude angle $(\Phi)$, solar declination angle $(\delta)$, solar hour angle $(\omega)$, solar altitude angle $(\psi)$, solar azimuth angle $\left(\mathrm{Y}_{\mathrm{s}}\right)$, solar incident angle $(\theta)$ and optimum tilt angle of the solar heating system $(\beta)$. These angles at latitude angle of Al-Ahsa $25.3^{\circ} \mathrm{N}$ on $21^{\text {st }}$ of June are summarized and listed in Table (1).

Under steady-state conditions, the useful heat delivered by the solar heating system is equal to the heat energy absorbed by the heat transfer fluid minus the direct or indirect heat losses from the surface to the surroundings. 
The useful energy collected from a collector can be obtained from the following formula (Duffie and Beckman, 2006):

$$
\mathbf{Q}_{u}=\mathbf{A}_{c}\left[\operatorname{SR}(\tau \alpha)-\mathrm{U}_{\mathrm{o}}\left(\mathrm{T}_{\mathrm{p}}-\mathrm{T}_{\mathrm{a}}\right)\right]=\mathbf{m} \mathbf{C}_{\mathrm{p}}\left(\mathbf{T}_{\mathrm{fo}}-\mathrm{T}_{\mathrm{fi}}\right) \text {, Watt }
$$

The heat transfer efficiency can be considered as the ratio of the useful heat gain to storage to that absorbed by the absorber plate. It can be estimated using the following formula:

$$
\eta_{\mathrm{h}}=\frac{q_{\mathrm{u}}}{\mathrm{q}_{\mathrm{a}}} \times 100, \quad \%
$$

Solar heating system overall thermal efficiency depends upon useful heat gain to storage and solar energy collected. The overall efficiency is the ratio of useful heat gain to storage to solar energy available. The overall thermal efficiency, $\eta_{0}$, can be computed from the following equation:

$$
\begin{gathered}
\eta_{0}=\frac{q_{u}}{I_{T} A_{c}} \times 100, \quad \% \\
\eta_{0}=\frac{m C_{p}\left(T_{f o}-T_{f i}\right)}{I_{T} A_{c}} \times 100,
\end{gathered}
$$

Table (1): Solar angles from sunrise to sunset on 21st day of June at Al-Ahsa with solar declination angle of $34.45^{\circ}$

\begin{tabular}{|l|c|c|c|c|c|}
\hline $\begin{array}{c}\text { Solar } \\
\text { Time, hr }\end{array}$ & $\begin{array}{c}\text { Solar hour } \\
\text { angle, } \boldsymbol{\omega}\end{array}$ & $\begin{array}{c}\text { Solar } \\
\text { altitude } \\
\text { angle, } \boldsymbol{\Psi}\end{array}$ & $\begin{array}{c}\text { Solar } \\
\text { azimuth } \\
\text { angle, } \boldsymbol{Y} \mathbf{s}\end{array}$ & $\begin{array}{c}\text { Solar } \\
\text { incident } \\
\text { angle, } \boldsymbol{\theta}\end{array}$ & $\begin{array}{c}\text { Optimum tilt } \\
\text { angle, } \boldsymbol{\beta}\end{array}$ \\
\hline $6: 00$ & -90 & 9.8 & -111.4 & 108.9 & 80.2 \\
\hline $7: 00$ & -75 & 22.6 & -106.3 & 95.3 & 67.4 \\
\hline $8: 00$ & -60 & 35.8 & -101.7 & 77.9 & 54.2 \\
\hline $9: 00$ & -45 & 49.1 & -97.3 & 58.9 & 40.9 \\
\hline $10: 00$ & -30 & 62.6 & -92.5 & 38.8 & 27.4 \\
\hline $11: 00$ & -15 & 76.2 & -85.5 & 18.6 & 13.8 \\
\hline $12: 00$ & 0 & 88.1 & 0 & 0 & 1.9 \\
\hline $13: 00$ & 15 & 76.2 & 85.5 & 18.6 & 13.8 \\
\hline $14: 00$ & 30 & 62.6 & 92.5 & 38.8 & 27.4 \\
\hline $15: 00$ & 45 & 49.1 & 97.3 & 58.9 & 40.9 \\
\hline $16: 00$ & 60 & 35.8 & 101.7 & 77.9 & 54.2 \\
\hline $17: 00$ & 75 & 22.6 & 106.3 & 95.3 & 67.4 \\
\hline $18: 00$ & 90 & 9.8 & 111.4 & 108.9 & 80.2 \\
\hline
\end{tabular}

\section{RESULTS AND DISCUSSION}

The solar stills have been operating satisfactorily from 7:00 to 17:00 for approximately five successive days without malfunction during June month of 2014. The ambient air temperature $\left(T_{\mathrm{a}}\right)$, glass cover temperature $\left(T_{g}\right)$, water vapour temperature, $\left(T_{v}\right)$, brackish water temperature $\left(T_{w}\right)$, intensity of solar radiation (R), and wind speed (V) were monitored and recorded. The daily production of distilled water and the intensity of solar radiation were measured, and the production of distilled water was also 
recorded each hour to study the effects of each parameter on the productivity of the solar stills.

Case 1: Thermal performance and productivity of the solar still double-slope (SSDS)

The experimental results from the solar still (SSDS) for five successive days are plotted in Fig. (4). The brackish water temperature increased gradually from the minimum value $\left(30^{\circ} \mathrm{C}\right)$ on the early morning $(7.00 \mathrm{hr})$ until reached the maximum value $\left(72.3^{\circ} \mathrm{C}\right)$ afternoon $(14.00 \mathrm{hr})$. It was decreased after that due to the heat energy losses from the basin of brackish water into the surrounding air were exceeded. Otherwise, at those times (afternoon) the heat energy losses from the solar still became larger than that absorbed from the solar radiation. Fig. (4) evidently revealed that the highest temperature was achieved by the water vapour the water particles had enough heat energy to evaporate. It also showed that, the temperature of glass cover was usually lower than that of the water vapour, except in the early morning when the difference was very small. Because the glass cover temperature was lower than the water vapour temperature, water vapour condensed on the inside surface area of the glass. In the early morning hours (from 7:00 to 9:00 hr), the water and vapour temperatures were closest to the glass temperature, which resulted in little production due to the small amount of heat energy absorbed by the water at those times.

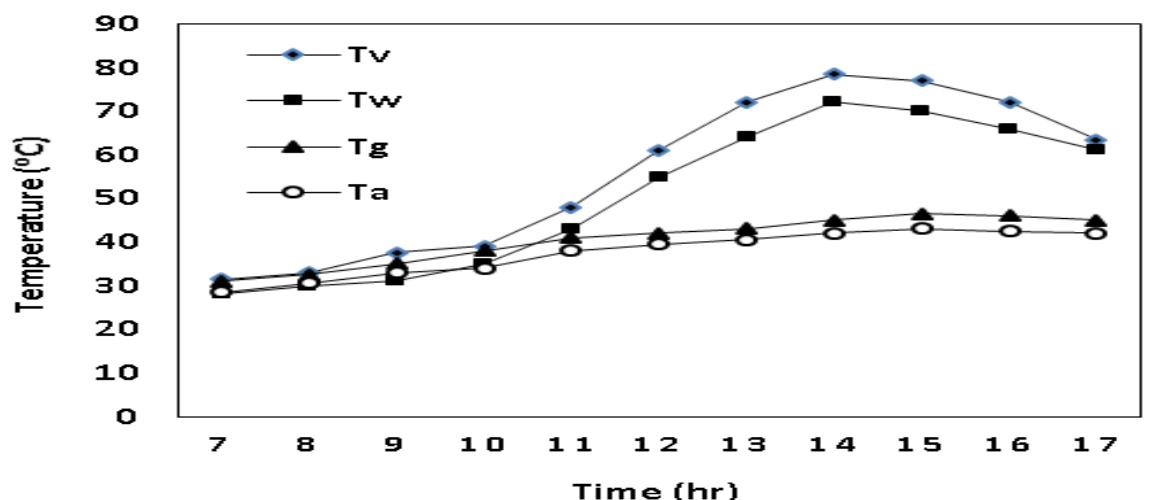

Fig.(4): Temperatures of different variables for the solar still (SSDS) versus the local standard time.

As the intensity of solar radiation inside the (SSDS) solar still increased, the production of freshwater increased because of the increase in heat energy absorbed by the brackish water resulting in increasing the vaporization rate inside the still. The production rate of freshwater changed from early morning until late afternoon, as illustrated in Fig. (4). The production of freshwater gradually increased from early morning till it reached the maximum value at afternoon as revealed in Fig. (5). The production then decreased until it reached the minimum value prior to sunset. The brackish water temperature was one of the important parameters that had a direct effect on the production of freshwater. The volumetric thermal efficiency of the solar still is the most important factor to evaluate the stiller because it reveals the best solar still design. The volumetric thermal efficiency of the 
(SSDS) solar still gradually increased from early morning (4.8\%) until it reached the maximum (28.3\%) afternoon (14:00hr), as illustrated in Fig. (6). The hourly average volumetric thermal efficiency for the (SSDS) solar still was $18.7 \%$. At the maximum values in the early afternoon, the intensity of solar radiation was higher than the losses of heat energy. Then, the heat energy losses exceeded than the intensity of the solar radiation (which decreased over time at afternoon). From previous results, it was concluded that as the intensity of solar radiation increased the temperature difference between the brackish water and ambient air increased considerably; the increase of the water temperature occurred through the convection process between the black surface of the basin and the brackish water. In the early morning, the temperature of the brackish water was low; therefore, a large amount of solar energy was needed to change the phase from saturated liquid to the saturated vapour phase. The obtained data revealed that the water temperature and heat energy required were inversely proportional. At early afternoon, the temperature of brackish water reached the maximum value $\left(72.3^{\circ} \mathrm{C}\right)$, and less heat energy was needed to vaporize the liquid, whereas the situation was reversed in the late afternoon. The hourly average temperature difference between the vapour and the glass cover of the solar still was $15.4^{\circ} \mathrm{C}$.

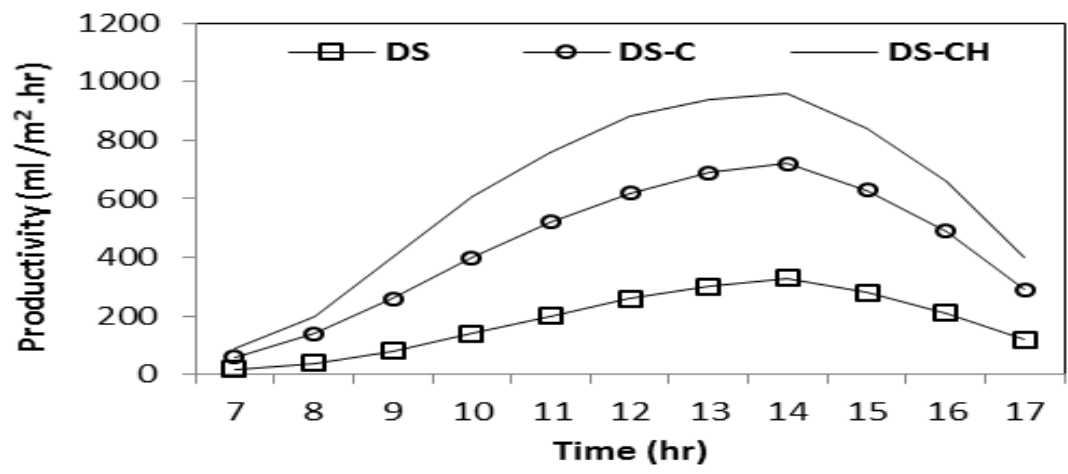

Fig. (5). Fresh water production versus local standard time for the double-slope (SSDS, SSDSC and SSDSSH) stills.

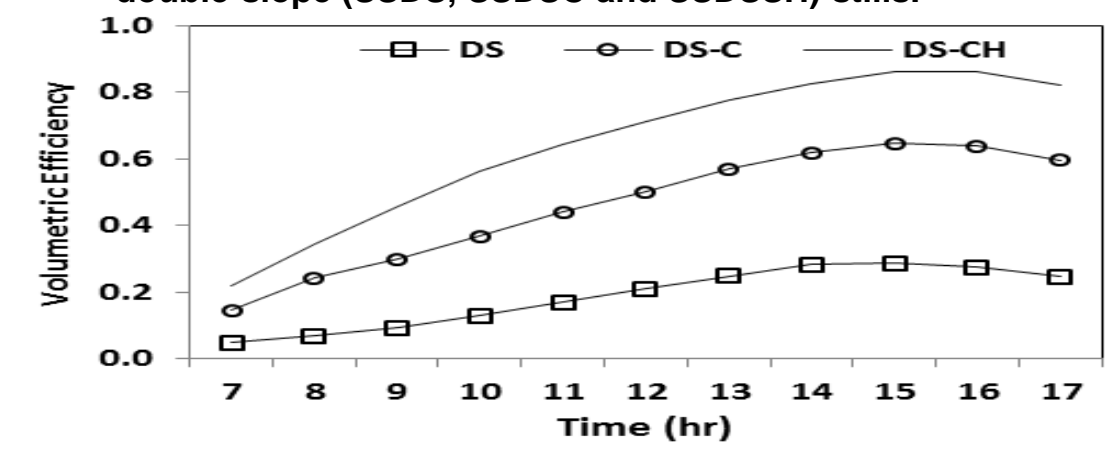

Fig. (6): Volumetric thermal efficiency of the SSDS, SSDSC and SSDSSH solar stills versus local standard time. 


\section{Case 2: The thermal performance and production of the (SSDSC) solar} still

A condenser was connected to the second solar still to increase the rate of vapour condensation on the inner surface of the condenser. Each shell of the condenser (the space between the inner and outer surfaces) was filled by cooled water from an evaporative cooling system attached to a small greenhouse. The cooled water temperature ranged from 18 to $21^{\circ} \mathrm{C}$. The means of different parameters within the (SSDSC) solar still were calculated, and the ambient air temperatures for five successive days were recorded. The data are presented in Table (2). The daily total intensity of solar radiation was $7347.2 \mathrm{~kW} \mathrm{~m}^{-2}$, with an hourly average solar radiation intensity of 667.9 $\mathrm{W} / \mathrm{m}^{2}$. The hourly average temperature difference between the vapour and the glass cover of the solar still was $22.1^{\circ} \mathrm{C}$. The maximum temperatures of brackish water $\left(79.2^{\circ} \mathrm{C}\right)$, vapour $\left(87.5^{\circ} \mathrm{C}\right)$, and glass cover $\left(51.1^{\circ} \mathrm{C}\right)$ of the solar still were also achieved at $(14.00 \mathrm{hr})$ afternoon. Accordingly, the maximum productivity rate of fresh water $\left(790 \mathrm{ml} / \mathrm{m}^{2}\right)$ and maximum volumetric efficiency $(61.8 \%)$ were realized at that time.

Within the solar still, the brackish water and water vapour temperatures continued to increase until the maximum values were reached at early afternoon (14:00 hr) because some heat energy accumulated inside the solar stills in the form of sensible heat. This occurred even though the maximum solar radiation intensity occurred at noon. The temperatures of the glass cover of the solar still also increased from early morning until the maximum value was approached afternoon because part of the heat from the water was transferred to the glass cover by free convection through the moist air, and the remaining heat was transferred by radiation. The glass covers transferred the heat into the atmosphere by convection and radiation. Lowering the glass cover temperatures below the water and outside air temperatures helped to increase the rate of heat and mass transfer. The temperature differences between the glass cover of solar still and the basin brackish water increased, which increased the natural circulation of the moist air mass inside the still. The natural circulation increased both the convective and evaporative heat transfers between the basin brackish water and the glass cover.

\section{Case 3: The thermal performance and production of the (SSDSSH) solar} still (with condenser and solar heater):

A condenser and a solar heater were connected to the third solar still to increase the rate of vapour condensation on the inner surface of the condenser as mentioned in case 2. However, the water was further heated by the solar water heater and returned back to the basin by natural circulation due to natural convection. The hourly average temperature difference between the vapour and the glass cover of the solar still was $23.71^{\circ} \mathrm{C}$. The maximum temperatures of brackish water $\left(84.8^{\circ} \mathrm{C}\right)$, vapour $\left(89.9^{\circ} \mathrm{C}\right)$, and glass cover $\left(53.8^{\circ} \mathrm{C}\right)$ of the solar still were also achieved at $(14.00 \mathrm{hr})$ afternoon. Accordingly, the maximum productivity rate of fresh water (1000 $\left.\mathrm{ml} / \mathrm{m}^{2}\right)$ and maximum volumetric efficiency $(88.3 \%)$ were realized at that time. 
Table (2): Hourly average ambient air temperature $\left(T_{a}\right)$, intensity of solar radiation $(R)$, water temperature $\left(T_{w}\right)$, water vapour temperature $\left(T_{v}\right)$, and glass cover temperature $\left(T_{g}\right)$ for the double-slope solar stills (SSDS, SSDSC and SSDSSH).

\begin{tabular}{|c|c|c|c|c|c|c|c|c|c|c|c|}
\hline \multirow{2}{*}{$\begin{array}{l}\text { Local } \\
\text { standard } \\
\text { time }\end{array}$} & \multirow{2}{*}{$\mathrm{T}_{\mathrm{a},}{ }^{\circ} \mathrm{C}$} & \multirow{2}{*}{$\begin{array}{c}\text { Solar } \\
\text { Radiation, } \\
\text { W/m }\end{array}$} & \multicolumn{3}{|c|}{$\begin{array}{c}\text { Double-slope } \\
\text { solar still (SSDS) }\end{array}$} & \multicolumn{3}{|c|}{$\begin{array}{c}\text { Double-slope } \\
\text { solar still } \\
\text { (SSDSC) }\end{array}$} & \multicolumn{3}{|c|}{$\begin{array}{l}\text { Double-slope } \\
\text { solar still } \\
\text { (SSDSSH) }\end{array}$} \\
\hline & & & & & 8 & $\begin{array}{l}\mathbf{T}_{\mathrm{w}} \\
{ }^{\circ} \mathrm{C}\end{array}$ & $\begin{array}{l}\mathbf{T}_{\mathrm{v}}, \\
{ }^{\circ} \mathrm{C}\end{array}$ & $\begin{array}{l}\mathrm{T}_{\mathrm{g}}, \\
{ }^{\circ} \mathrm{C}\end{array}$ & $\begin{array}{l}\mathbf{T}_{\mathrm{w}}, \\
{ }^{\circ} \mathbf{C}\end{array}$ & $\begin{array}{l}\mathbf{T}_{\mathrm{v},} \\
{ }^{\circ} \mathrm{C}\end{array}$ & $\mathrm{T}_{\mathrm{g}},{ }^{\circ} \mathrm{C}$ \\
\hline 7.00 & 33.8 & 362.2 & 27.8 & 31.5 & 31.0 & 35.6 & 39.3 & 34.6 & 34.2 & 41.2 & 34.9 \\
\hline 8.00 & 38.1 & & & & 32.5 & 40.0 & 44.2 & 38.2 & 40.8 & 47.1 & 38.8 \\
\hline 00 & 40.7 & & & & 35.0 & 43.5 & 48.0 & 41.5 & 44.2 & 51.2 & \\
\hline 0.00 & 42.8 & & & & 38.0 & 50.8 & 56.1 & \begin{tabular}{|l}
44.2 \\
\end{tabular} & 55 & 58.3 & \\
\hline 18 & 44.2 & & & & & 59.2 & 65.4 & 47.0 & & 67.6 & \\
\hline 12.0 & 45.4 & & & 1.0 & 42.1 & 69.2 & 76.4 & 48.4 & 74.6 & 79.8 & 49.2 \\
\hline 1 & 5.8 & & & 72.1 & 42.8 & 78.0 & 86.1 & 49.5 & 79.6 & 88.6 & 51.3 \\
\hline 14.0 & 5.7 & & & 78.5 & 45.3 & 79.2 & 87.5 & 51.1 & 84.8 & 89.9 & 53.8 \\
\hline 15.0 & 5.8 & & & 77.0 & 46.5 & 77.3 & 85.3 & 50.7 & 80.3 & 87.8 & 52.6 \\
\hline & 5.2 & & & 72.3 & 46.0 & 73.4 & 81.0 & 499.7 & 76.2 & 84.7 & 50.4 \\
\hline 17.00 & 43.2 & & 61.1 & 63.5 & 44.7 & 68.8 & 76.0 & 48.3 & 70.6 & 80.3 & 49.2 \\
\hline Total & - & & 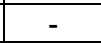 & & - & & - & - & - & - & - \\
\hline Mean & 42.8 & 681.5 & 50.6 & 55.8 & 40.4 & 61.4 & 67.8 & 45.7 & 64.1 & 70.6 & 46.9 \\
\hline
\end{tabular}

Fig. (7) illustrates the hourly average production of freshwater from the three solar stills (SSDS, SSDSC and SSDSSH). The production rate of freshwater varied from hour to hour and day to another. For the duration of the experimental work, the daily average production of freshwater from the three stills, respectively, were $1.98,4.82$, and 6.65 litres per square meter. Therefore, adding a condenser to the solar still (SSDSC) increased the daily average production of freshwater from 1.98 to 4.82 litres per square meter, with an average increasing rate of $143.4 \%$. Because the inner surface temperature of the condenser was much lower than the water vapor temperature, the condensation rate increased on the inner surfaces. In the early morning hours (7:00-8:00), the temperature differences between the inside parameters (brackish water and water vapour temperatures) of the solar still and the inner surface of the condensers was lower than at other times, which resulted in lower freshwater production. The solar still connected to the solar heating system increased the daily average production of distilled water from 4.82 to 6.65 litres per square meter, with an average increasing rate of $38 \%$. The volumetric thermal efficiency of the solar still with a condenser (SSDSC) gradually increased with time from early morning $(14.5 \%)$ until it reached the maximum value $(61.8 \%)$ afternoon (at 14:00 hr), as illustrated in Fig. (6). The hourly average volumetric thermal efficiency for the solar still using a condenser was $46 \%$. The condenser was designed according to the cover material used for the conduction and convection of the latent heat of condensation at the inner surface of the condenser. The condensers used circular shells to enhance the convective heat transfer and consequently increased the rate of production and the volumetric thermal efficiency. Therefore, using a condenser with the solar still increased the 
volumetric thermal efficiency by $146.3 \%$ compared with the efficiency of the solar still without a condenser.

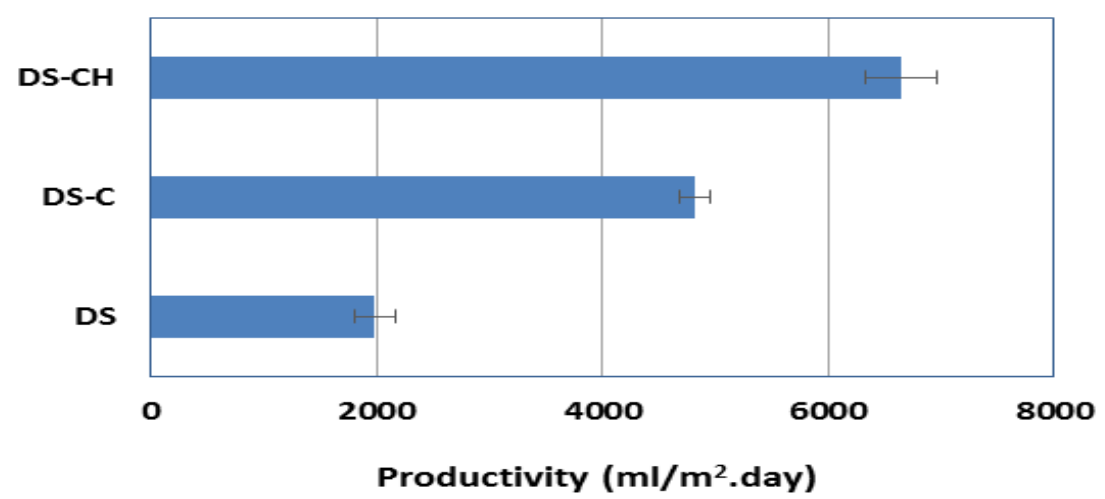

Fig. (7): Productivity rate of freshwater from the three double-slope solar stills.

The volumetric thermal efficiency of the solar still connected to a condenser and a solar water heating system (SSDSSH) gradually increased with time from the early morning $(21.7 \%)$ till it reached the maximum value $(86.1 \%$ ) in the early afternoon (at 15:00), as is illustrated in Fig. (6). The hourly average volumetric thermal efficiency of the solar still using a condenser and a solar heater was $64.4 \%$. The solar water heating system increased the basin brackish water temperature and increased the evaporation rate, resulting in increasing the rate productivity of freshwater. Therefore, the integrated double-sided solar distiller with a condenser and a solar heating system (SSDSSH) increased the production of freshwater and consequently, the volumetric thermal efficiency by $235.9 \%$ and $244.5 \%$, respectively, as compared with the stand-alone solar still. Additionally, the volumetric thermal efficiency increased by $39.9 \%$ as compared with the efficiency of the solar still integrated with a condenser only.

\section{Thermal Performance of the Solar Water Heating System}

Under clear sky conditions, solar radiation flux incident, solar energy available, absorbed solar energy, and overall thermal efficiency of the water heating system increased gradually with solar time from sunrise until it reached the maximum amount at noon. It then decreased gradually till it reached the minimum value prior to sunset. For the duration of the experimental work, the daily average solar energy available was $14.993 \mathrm{kWh}$. Actual solar radiation data recorded on a clear day ranged from near zero to about $1000 \mathrm{~W} / \mathrm{m}^{2}$. Therefore, the absorbed solar energy was varied from sunrise to sunset according to the incoming solar radiation and the solar incidence angle, which was strongly, affected by the optical efficiency. The daily average absorbed solar energy was $11.485 \mathrm{kWh}$ which gave an average absorption efficiency of $76.6 \%$. The absorbed solar energy $\left(Q_{a}\right)$ by the absorber plate was plotted against solar energy available (SR) as shown in Fig. (8). Regression analysis revealed a highly significant linear relationship $(r=0.994)$ between these parameters. The best fit equations relating the absorbed solar energy to solar energy available were: 


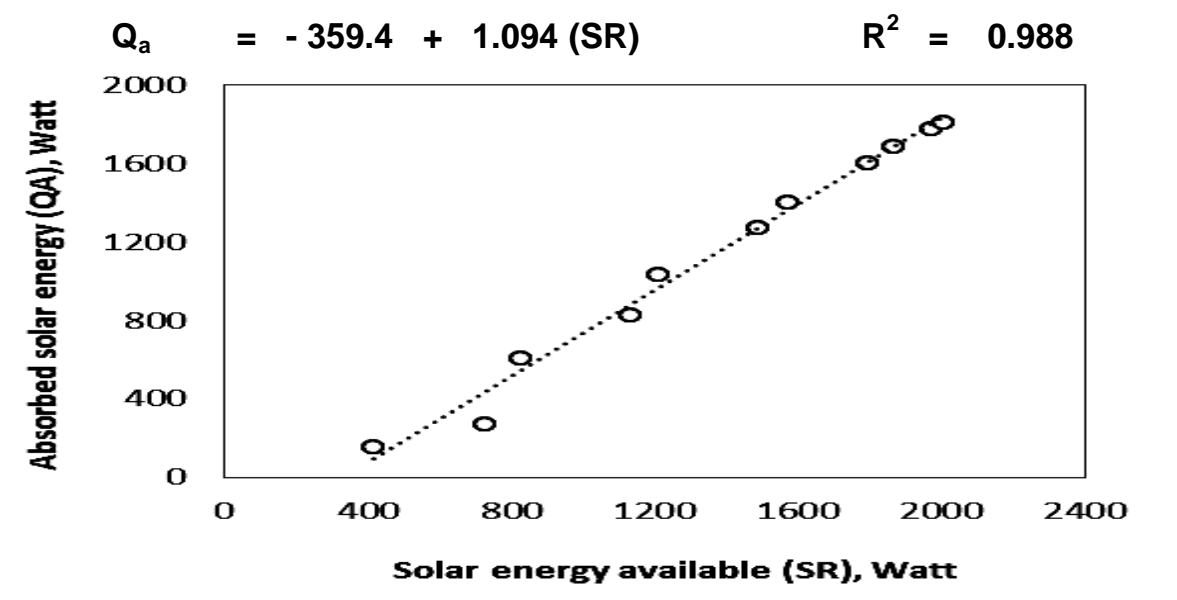

Fig. (8): Absorbed solar energy versus available solar energy.

Mathematical analysis of the measured data revealed that, during early morning just after sunrise and just prior to sunset (when the solar radiation flux incident on a horizontal plane at these times is less than 200 $\mathrm{W} / \mathrm{m}^{2}$ and at the same time, the internal and external ambient air temperatures are less than the water temperature in the solar heating systems), very little useful heat was gained by the water passing through the solar heating system. Also, it was noticed that, the working fluid (water) dissipated some of its heat energy into the internal ambient air particularly just after sunrise and before sunset. Fig. (9) reveals the inlet and outlet water temperatures of the solar water heating system for the solar still (SSDSSH), and the maximum difference in water temperature occurred approximately at noon. Heat transfer efficiency depends strongly upon the differences in temperature between the operating temperature of the absorber surface and the temperature of the water passing through the solar heating system. As the difference in temperature between the absorber surface and the water passing through the solar heater is increased the heat transfer between the absorber surface and the working fluid (water) is increased making the system more efficient. As the water inlet temperature increased, the difference in temperature between the absorber surface and the water passing through the solar heater is reduced and heat transfer efficiency is thus decreased. Therefore, the daily average useful heat gain to storage by the solar water heating system was $10.308 \mathrm{kWh}$ which provided an overall thermal efficiency of $68.75 \%$. 


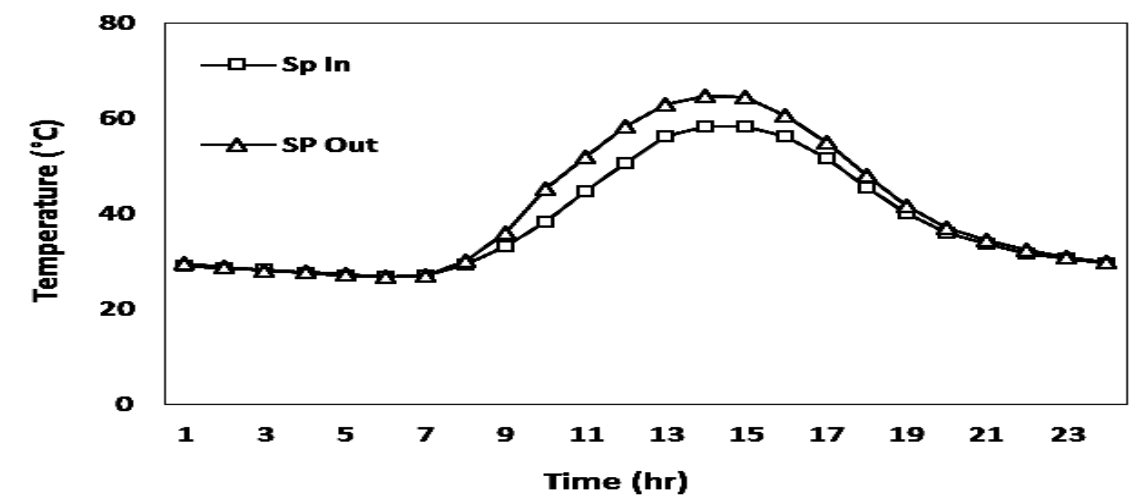

Fig. (9): Inlet and outlet water temperatures of the solar water heating.

Effects of a dust storm and accumulated dust on solar still efficiency

During high level of wind speed blowing over the top surfaces of solar stills and solar heating system, a high level of dust was accumulated on those surface resulting in reducing the intensity of solar radiation flux incident inside the solar systems and consequently, the heating effect was reduced as well. As result, the basin water temperature and vapour temperature dropped and reduced the productivity rate of the solar stills. The accumulation of dust on the top surface of solar still glass cover reduced the water temperature as compared with clean glass cover because the accumulating dust prevented the majority of solar radiation from penetrating the still glass. The production of the solar still was reduced as shown in Figs. (10) and (11). Therefore, clean solar still glass cover was a crucial factor to reach the maximum production. The deposition of dust, in addition to the reduction in solar radiation intensity caused by atmospheric dust, decreased the production of distilled water by $63 \%$ (Fig. 12).

\section{Quality of distilled water}

The obtained date revealed that, the $\mathrm{pH}, \mathrm{EC}$, and TDS of solar distilled water were found to be much lower $(7.8,42.9 \mu \mathrm{s} / \mathrm{cm}$, and $39.7 \mathrm{ppm}$, respectively) than those of the brackish water $(8,1417 \mu \mathrm{s} / \mathrm{cm}$, and $1392 \mathrm{ppm}$, respectively). The quality of water distilled from the solar stills was suitable for drinking, particularly in remote areas. Moreover, the distilled water that was produced can be returned to the evaporative cooling system reservoir to help in reducing salt buildup on the cooling pads, (clogging pads), which will enhance and increase the effectiveness of the evaporative cooling system. Thus, the system can be integrated with the evaporative cooling system.

\section{CONCLUSION}

The volumetric thermal performance of a double-slope (SSDS) solar still was compared with an integrated still with a condenser only (SSDSC) and with an integrated still with a condenser and a solar water heating system (SSDSSH). 


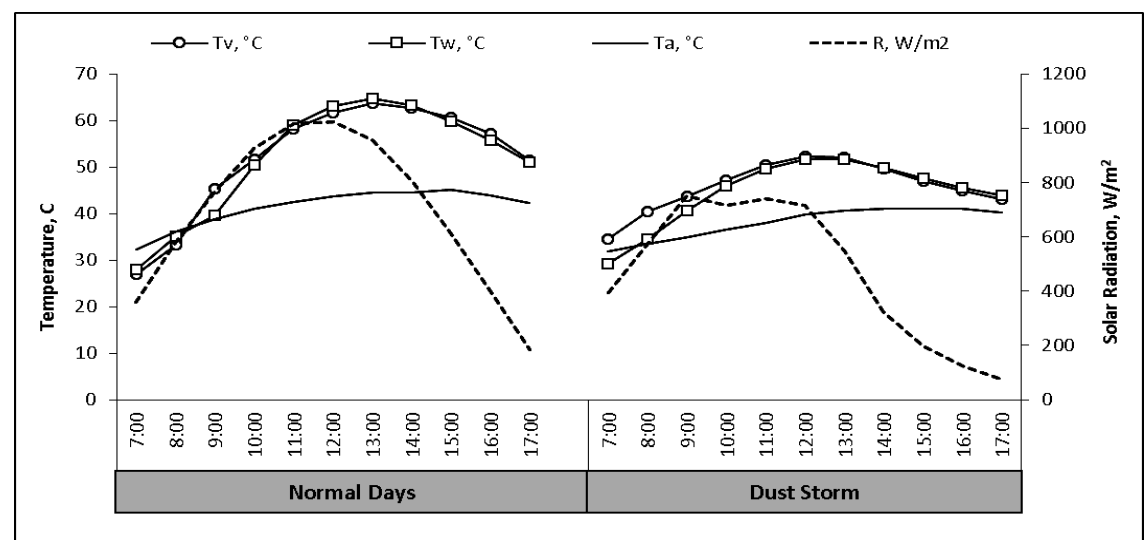

Fig. (10): Effect of dust storm and accumulated dust on the solar still (SSDS) parameters.

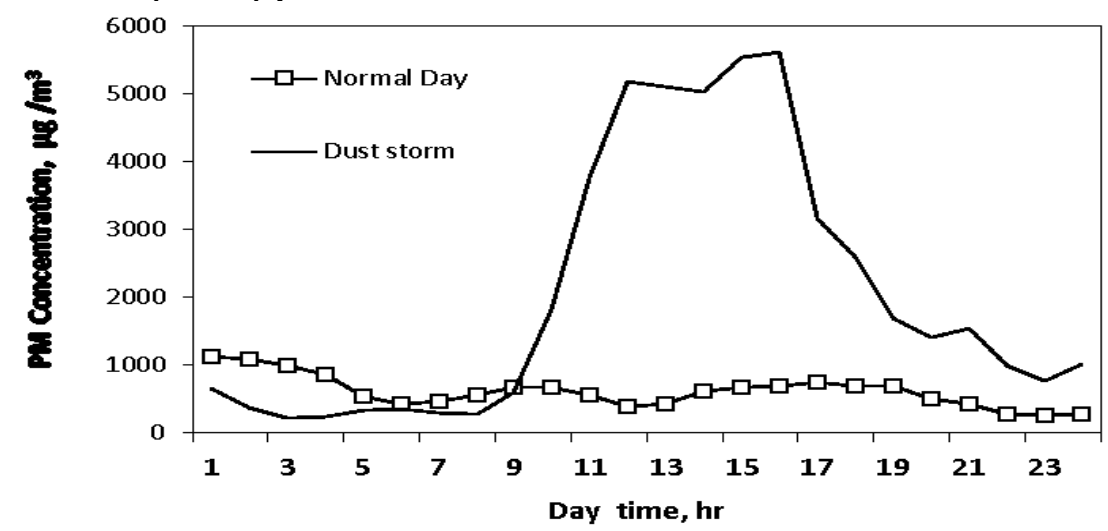

Fig. (11): Dust concentrations during high level of wind speed as compared with a normal day.

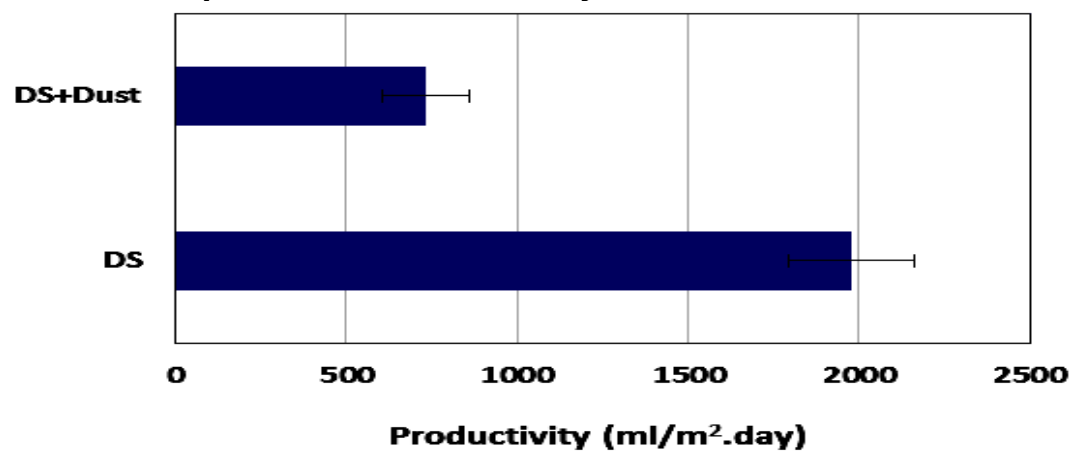

Fig. (12): Freshwater production rate for the double-slope (DS) stills during a dust event compared with a normal day.

The condensers were supplied with cold water from an evaporative cooling system of an experimental greenhouse situated beside the solar still 
system. The thermal performance of the stills was examined under hot, humid, and dusty climatic conditions of Al-Ahsa (eastern province), Saudi Arabia. From this research work, the following conclusion has been drawn:

1. An increase in either the intensity of solar radiation or the inside moist air temperature increased the production of the solar stills. As the intensity of the solar radiation inside the solar still increased, the productivity rate of freshwater increased because of the increase in heat energy gained from brackish water vaporization inside the stills.

2. The hourly average solar radiation available outside the tilted surface of solar stills was $681.5 \mathrm{Wm}^{-2}$, of which $567.7 \mathrm{Wm}^{-2}$ were available inside the SSDS solar stills with an average effective transmittance of 0.833 . The temperatures of brackish water and water vapour inside the still gradually increased from early morning until reached the maximum value afternoon (14:00 hr).

3. The maximum production and high efficiency of the solar still (SSDS) occurred early afternoon due to the high heat energy accumulated inside the solar stills. The daily average production rate of distilled water was 1.980 litres per square meter, and the volumetric thermal efficiency of the distiller was $18.7 \%$.

4. A solar still equipped with condenser (SSDSC) to provide cooled water for increasing the productivity rate of potable water significantly increased the production of freshwater and the volumetric thermal efficiency of the solar still. The daily average production rate of distilled water was 4.82 litres per square meter, and the volumetric thermal efficiency of the distiller was $46 \%$. Consequently, this set of solar still increased the production rate of water and the volumetric thermal efficiency by $143.4 \%$ and $146.3 \%$, respectively, as compared with the first set.

5. The solar still equipped with condenser and solar heating system (SSDSSH) increased the production rate of freshwater and the volumetric thermal efficiency by $235.9 \%$ and $244.5 \%$, respectively, as compared with the first set. The daily average production rate of distilled water was 6.65 litres per square meter, and the volumetric thermal efficiency of the distiller was $64.4 \%$. Consequently, this integrated system increased the production rate of freshwater and the volumetric thermal efficiency by $38 \%$ and $39.9 \%$, respectively, as compared with the second set (SSDSC).

6. Cleaning the top surface of the solar still glass cover is a crucial factor to maintain the maximum production of water.

\section{REFERENCES}

Abdellatif, S. M.; N. M. Elashmawy; and A. M. Kassem (2009) "Optimum tilt angle and orientation for a flat plate solar water heater under Egyptian conditions" AMA (Agricultural Mechanization in Asia, Africa, and Latin America), Vol. 40, No. 3:73-77

Al-Hinai, H.; M. S. Al-Nassri; and B. A. Jubran (2002) "Effect of climatic, design and operational parameters on the yield of a simple solar still" Energy Conversion Management, 43: 1639-1650. 
Abdel-Rehim, Z. S.; and A. Lashine (2012) "A Study of Solar Desalination Still Combined with Air-Conditioning System" International Scholarly Research Network-Renewable Energy. Article ID 212496: 1-7.

Abu-Arabi, M.; Y. Zurigat; H. Al-Hinai; and S. Hiddabi (2002) "Modeling and performance analysis of a solar desalination unit with double-glass cover cooling" Desalination, 143: 173-182

Ahmed, E. M.; O. Abaas; M. Ahmed; and M. R. Ismail (2011) "Performance evaluation of three different types of local evaporative cooling pads in greenhouses in Sudan" Saudi J. of Biological Sciences, 18: 45-51.

Al-Ansari, M. S. (2013) "Concentrating solar power to be used in seawater desalination within the Gulf Cooperation Council" Energy and Environment Research, 3 (1): 10-23.

Al-Hayek, I.; and O. O. Badran (2004) "The effect of using different designs of solar stills on water distillation" Desalination, 169, (2): 121-127.

Almuhanna, E. A. (2014) "Evaluation of Single Slop Solar Still Integrated with Evaporative Cooling System for Brackish Water Desalination" J. of Agricultural Science, 6(1): 48-58.

ASHRAE, (2005) "Handbook of Fundamentals" American Society of Heating, Refrigerating and Air Conditioning Engineers, New York, USA

Badran, A. A.; and H. A. Al-Tahaineh (2005) "The effect of coupling a flatplate collector on the solar still productivity" Desalination, 183: 137142

Badran, O. O.; and M. M. Abu-Khader (2007) "Evaluating thermal performance of a single slope solar still. Heat mass Transfer" 43: 985-995.

Chaibi, M. T. (2000) "An overview of solar desalination for domestic and agriculture water needs in remote arid areas" Desalination, 127: 119133

Diekmann, R. (2008) "Solar and Wind Energy" International Issue 5, Bielefelder Verlag GmbH \& Co., Belfield

Duffie, J.A.; and W. A. Beckman (2006) Solar engineering of thermal processes. New York, N.Y.: John Wiley and Sons.

Goosen M. F. A.; S. S. Sablani; C. Paton; J. Perret; A. Al-Nuaimi; I. Haffar; H. Al-Hinai, and W. H. Shayya (2003) "Solar energy desalination for arid coastal regions: development of a humidification-dehumidification seawater greenhouse" Solar Energy, 75: 413-419

Goosen, M. F. A.; A. A. Sablani; W. H. Shayya; C. Paton; and H. Al-Hinai (2000) "Thermodynamic and economic considerations in solar desalination" Desalination, 129: 63-89

Helmy E.; G. S. M. El-Gayar; and H. E. Gad (2011) "Performance of a solar still with clothes moving wick" Fifteenth International Water Technology Conference, IWTC 2011, Alexandria, Egypt.

Hepbasli, A.; and Z. Alsuhaibani (2011) "A key review on present status and future directions of solar energy studies and applications in Saudi Arabia" Renewable and Sustainable Energy Reviews, 15: 5021-5050.

Kalogirou, S. M. (2005) "Seawater desalination using renewable energy sources" Progress in Energy and Combustion Science, 31: 242-281. 
Khan S. I.; and A. Islam (2011) "Performance Analysis of Solar Water Heater" Smart Grid and Renewable Energy, 2:396-398.

Li, C.; Y. Goswami; and E. Stefanakos (2013) "Solar assisted seawater desalination: A review" Renewable and Sustainable Energy Reviews, 19: 136-163.

Mechell, J. K.; B. J. Lesikar; and S. C. Capareda (2011) "performance characteristics of four solar still designs" Applied Engineering in Agriculture, 27(3): 425-432.

Murugavel, K. K.; K. S. K. Chockalingam; and K. Srithar (2008) "Progresses in improving the effectiveness of the single basin passive solar still. Desalination, 220: 677-686.

Radhwan, A. M. (2004) "Transient analysis of a stepped solar still for heating and humidifying greenhouse" Desalination, 161: 89-97

Radhwan, A. M.; and H. E. S. Fath (2005) "Thermal performance of greenhouse with a built-in solar distillation system: experimental study" Desalination, 181: 193-205.

Swetha, K.; and J. Venugopal (2011) "Experimental investigation of a single slopes solar still using pcm" International Journal of Research in Environmental Science and Technology, 1(4): 30-33.

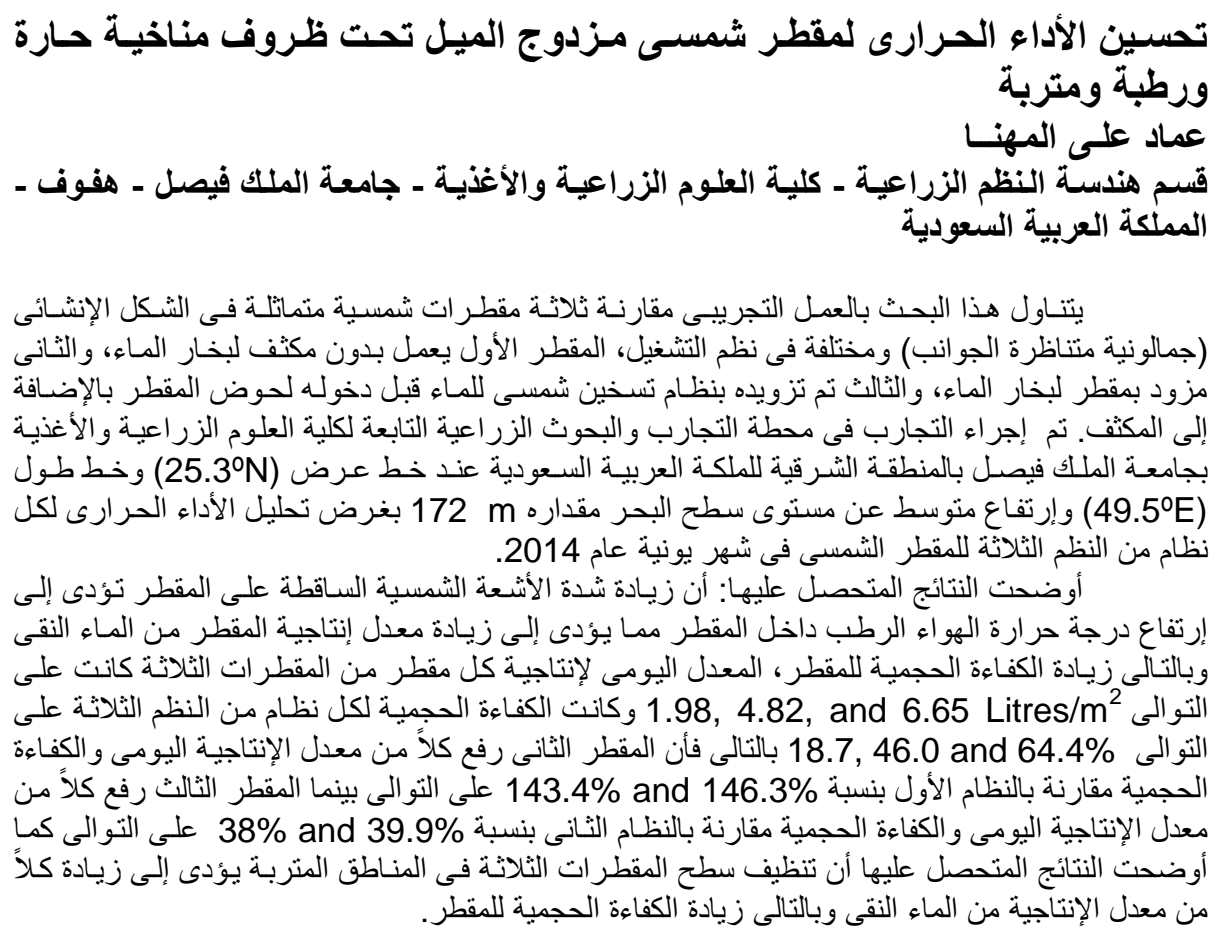

